\title{
Pióra w służbie buławy. Raz jeszcze o kancelarii i archiwum hetmańskim Stanisława Jabłonowskiego ${ }^{1}$
}

Archiwa hetmanów koronnych w dawnej Rzeczypospolitej były już przedmiotem wyczerpujących opracowań ${ }^{2}$ i choć spuścizna archiwalna hetmana wielkiego koronnego, kasztelana krakowskiego Stanisława Jana Jabłonowskiego była wykorzystywana w nich incydentalnie, to jej zawartość omówiono pokrótce w biografii tegoż hetmana ${ }^{3}$. Niemniej jednak dotychczasowe prace opisywały archiwa hetmańskie głównie z perspektywy archiwistycznej - starając się określić ich charakter i dokonać klasyfikacji znajdujących się w nich materiałów, albo traktowały je po prostu jako podstawę źródłową do studiów nad działalnością poszczególnych hetmanów bądź - ogólnie - nad wojskowością polską w danym okresie. W pierwszym przypadku mamy zatem do czynienia ze spojrzeniem niejako ex post - uznającym poszczególne archiwa hetmańskie za pewną zamkniętą całość, $\mathrm{w}$ drugim zaś - z ich raczej instrumentalnym wykorzystaniem. Tymczasem problematyka praktyki dokumentacyjnej i archiwalnej administracji hetmańskiej zasługuje, aby przyjrzeć się jej także w kontekście

${ }^{1}$ Autor chciałby podziękować Fundacji im. Augusta hr. Cieszkowskiego za przyznanie stypendium, które pozwoliło przeprowadzić badania będące podstawą niniejszego studium.

${ }^{2}$ K. Syta, Archiwa hetmanów koronnych, [Toruń 1997], maszynopis rozprawy doktorskiej w Archiwum Uniwersytetu Mikołaja Kopernika w Toruniu; idem, Dokumentacja wojskowa w archiwach hetmanów koronnych, „Miscellanea Historico-Archivistica” 2001, t. XIII, s. 51-67; idem, Archiwa hetmanów koronnych: Pojęcie, charakter i typologia dokumentacji, „Archiwa - Kancelarie - Zbiory" 2011, nr 2 (4), s. 63-105; idem, Materiaty do przewodnika po archiwaliach hetmanów koronnych w zasobach archiwalnych i zbiorach bibliotecznych, ibidem, 2012, nr 3 (5), s. 109-182.

3 M. Wagner, Stanisław Jabłonowski (1634-1702): Polityk i dowódca, Siedlce 1997, t. I, s. 11$12,17-18$. 
jej własnej epoki - jako istotnemu narzędziu sprawowania hetmańskiej władzy i kontroli nad siłami zbrojnymi. Wymaga to przede wszystkim uwzględnienia aspektów historyczno-ustrojowych i historyczno-wojskowych, czyli analizy zachowanej dokumentacji hetmańskiej w ścisłym powiązaniu z wiedzą zarówno na temat ustrojowych podstaw funkcjonowania tego urzędu ${ }^{4}$, jak i faktycznego dowodzenia armiami Rzeczypospolitej.

Archiwum hetmańskie Stanisława Jabłonowskiego jest najlepiej zachowanym archiwum hetmańskim z drugiej połowy XVII w. - okresu największego pod względem liczbowym wysiłku wojennego Rzeczypospolitej. Czas piastowania buławy wielkiej przez Jabłonowskiego (1683-1702) przypada na lata wojny z Imperium Osmańskim (1683-1699) - jednej z najdłuższych wojen toczonych przez Rzeczpospolitą w siedemnastym stuleciu. Tym samym analiza dokumentacji wytworzonej przez kancelarię tegoż hetmana przynosi sporo informacji na temat działalności administracji wojskowej w momencie jej największego znaczenia dla funkcjonowania całego państwa - podczas długotrwałego konfliktu zbrojnego niosącego ze sobą spore wyzwania o charakterze logistycznym, finansowym i dyscyplinarnym. Rzetelnie prowadzona dokumentacja mogła być dla hetmana istotną pomocą w przezwyciężeniu tych trudności.

W drugiej połowie XVII w. przywileje nominacyjne kolejnych hetmanów koronnych dość ogólnikowo określały kompetencje tego urzędu. Dobrym przykładem może być przywilej Jana III dla ks. Dymitra Jerzego Wiśniowieckiego, wojewody bełskiego, z 15 marca 1676 r.: ,cui [ks. Dymitrowi Wiśniowieckiemu] supremam exercitus regni praefecturam demus et conferamus prout de facto damus et conferimus praesentibus litteris nostris per ipsum cum omnibus iuribus, praerogativis, iurisdictione, proventibus et utilitatibus ad hoc munus et dignitatem de legum praescripto et consuetudine spectantibus et pertinentibus, gerendum, tenendum et administrandum ad extrema vitae ipsius tempora, vel maioris alicuius

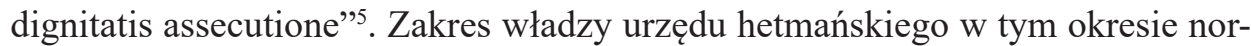
mował zatem przede wszystkim zwyczaj, jak i prawo pisane - konstytucje sejmowe, wśród których szczególną rolę odgrywały aprobowane przez sejm $1609 \mathrm{r}$. Artykuły wojenne hetmańskie ${ }^{6}$ o czym świadczy fakt częstego powoływania się

${ }^{4}$ Zauważył to Krzysztof Syta: „Następny czynnik, mający wpływ na charakter archiwów hetmańskich, to znaczenie urzędu hetmana w okresie sprawowania go przez daną osobę. Chodzi mianowicie o jego uprawnienia i obowiązki, o jego prawne opisanie", K. Syta, Archiwa hetmanów..., s. 73 .

${ }^{5}$ Oblata privilegii super generalem praefecturam exercitus Regni, Kraków, 15 III 1676, Archiwum Główne Akt Dawnych w Warszawie [dalej: AGAD], Metryka Koronna, sygn. 211, s. 207.

${ }^{6}$ O kulisach uzyskania aprobaty sejmowej dla artykułów wojskowych w 1609 r.: K. Łopatecki, „Disciplina militaris” w wojskach Rzeczypospolitej do połowy XVII wieku, Białystok 2012, s. 609-629. 
na nie jako na jedno ze źródeł władzy hetmana w obowiązujących formułach różnych pism przygotowywanych w kancelarii hetmańskiej ${ }^{7}$.

Dobrym przykładem sposobu dokumentowania działalności hetmana wielkiego za czasów Stanisława Jabłonowskiego jest jedna z podstawowych kompetencji tego urzędu, a mianowicie dowodzenie wojskiem. Jak słusznie zauważył Przemysław Gawron, bezpośrednie kierowanie jego działaniami armii w trakcie kampanii nie należało pierwotnie do najważniejszych prerogatyw hetmańskich. Jeszcze w połowie XVI w. dużo większą wagę przywiązywano do uprawnień o charakterze administracyjno-dyscyplinarnym ${ }^{8}$. Jednakże pod koniec tego stulecia w Koronie utarło się, że - o ile w działaniach wojennych nie bierze udziału monarcha - to właśnie hetman wielki, a w razie jego nieobecności polny, przewodzi armii ${ }^{9}$. W interesującym nas okresie wyjątkiem była kampania 1687 r., kiedy to oficjalnym dowódcą wojsk polsko-litewskich został desygnowany królewicz Jakub Ludwik, pierworodny syn Jana III. Był to jednak zabieg o charakterze wyłącznie propagandowym. Faktyczną komendę sprawował nadal hetman Stanisław Jabłonowski, a uznanie przez niego nominalnej władzy królewicza należy traktować jako akt sympatii wobec królewskiej polityki dynastycznej.

Co szczególnie istotne w kwestii dokumentacji wojskowej: za czasów hetmaństwa Jabłonowskiego było już przyjętą praktyką, że nawet podczas obecności samego króla w obozie to hetman wielki koronny wydawał i sygnował bezpośrednie ordynanse (rozkazy) wojsku koronnemu. Przykładowo, w swojej relacji z działań wojennych z lat 1685-1688 składanej przed sejmem w 1689 r. ówczesny wojewoda ruski stwierdzał, że 22 sierpnia 1686 r. w czasie wyprawy do Mołdawii to król zdecydował, aby wyprawić przeciw nieprzyjacielowi zgrupowanie wojska pod dowództwem płka Michała Floriana Rzewuskiego, podskarbiego nadwornego koronnego, złożone zarówno z oddziałów koronnych, jak i litewskich ${ }^{10}$. Tymczasem

7 O kształtowaniu się władzy hetmańskiej w pierwszej połowie XVII w.: P. Gawron, Hetman koronny w systemie ustrojowym Rzeczypospolitej w latach 1581-1646, Warszawa 2010; bardziej syntetyczne (ale i niezbyt aktualne) omówienia kompetencji hetmana: S. Kempski, Władza buławy, „Przegląd Historyczno-Wojskowy” 1935, t. VII/2, s. 187-215; S. Woliński, Urzędy hetmańskie w świetle ustawodawstwa polskiego, „Przegląd Historyczno-Wojskowy” 1933, t. VI/1, s. 61-80.

${ }^{8}$ P. Gawron, op.cit., s. 45

9 Krystalizacja kompetencji hetmańskich dotyczących rządu nad oddziałania kształtowała się i w 1 poł. XVI stulecia. W konsekwencji tzw. ,wojny kokoszej” z 1537 r. hetmani koronni utracili prawo do dowodzenia nad pospolitym ruszeniem. K. Łopatecki, Organizacja, prawo i dyscyplina w polskim i litewskim pospolitym ruszeniu (do połowy XVII wieku), Białystok 2013, s. 122-123, 570-571.

${ }^{10}$ [S.J. Jabłonowski], Relacja praeclare gestorum wojska JKM $i$ Rzeczypospolitej w czteroletnych kampaniach poczawszy ab anno 1685, aż do teraźniejszego sejmu in anno 1688 zaczętego sub auspicii wielkiej buławy JW Jm Pana Stanisława Jana na Jabłonowie Jabłonowskiego wojewody i generała ziem ruskich, hetmana wielkiego koronnego, [Warszawa], 12 II [1689], Biblioteka Polskiej Akademii Umiejętności i Polskiej Akademii Nauk w Krakowie, sygn. 1081, s. 33. Na temat 
tego samego dnia to Jabłonowski wydał na piśmie ordynans Rzewuskiemu, aby wziął pod swoją komendę 23 chorągwie jazdy koronnej, 400 żołnierzy dragonii i wszystkie obecne w obozie oddziały wojska zaporoskiego i „poszedł z pomienionym wojskiem [...] na pewną imprezę, jako od Jego Królewskiej Miłości ustną bierze informacyją [...] i ode mnie" ${ }^{11}$. Zapewne analogiczny ordynans dla chorągwi litewskich wydał hetman wielki litewski Kazimierz Jan Sapieha. Usankcjonowana zwyczajem zasada bezpośredniego wydawania ordynansów wojsku przez hetmana nawet w obecności króla doprowadziła w $1698 \mathrm{r}$. do poważnej scysji pomiędzy Jabłonowskim a nieświadomym tego faktu nowym królem Augustem II: 22 września tegoż roku w obozie wojska koronnego pod Telaczami: „[Jan] Sobieski, cześnik koronny i strażnik wojskowy per ostentationem urzędu swego przyszedł daleko po bankiecie między pijanych do kotary mego ojca [Stanisława Jabłonowskiego], gdzie i król był, a przyszedł w pancerzu, w karwaszach jak do boju, prosząc mego ojca, żeby ordynans chorągwi podpisał, która miała iść na forwacht przed obóz. Ja [Jan Stanisław Jabłonowski, wojewoda ruski, syn hetmana] i nieboszczyk [Wojciech Stanisław] Czacki, pisarz wojskowy mówimy mu, aby odłożył do jutra, nie będąc nic pilnego, a mój ojciec będąc pijany, ale on nie słuchając, mego ojca importunuje. Król pijany to obaczywszy a nie wiedząc, co to było, mówi mojemu ojcu: co to ci za papier on daje? Mój ociec wstydząc się tej bagateli, rzekł królowi: nic to mości królu. Król mówi: ale ja chcę wiedzieć, co to jest? Hetman: to jest rzecz, która do mnie nie do Waszej Królewskiej Mości należy. Rozgniewał się król pijany: jako jest co w komendzie wojskowej, coby król wiedzieć nie miał? Hetman: i bardzo siła jest Mości Królu z czego królowi hetman sprawować się nie powinien. Rozjadł się król, ale i przy pijaństwie wielki dyssymulant nic nie rzekł, rozpiął kotarę i do swoich namiotów poszedł [...], mówiąc: pójdźmy pić do siebie"12.

W drugiej połowie XVII w. regułą było, że ordynanse hetmańskie miały formę pisemną ${ }^{13}$. Nawet jeśli hetman uznawał, że ze względu na ochronę tajemnicy wojskowej należy zasadniczą treść rozkazu przekazać adresatowi ustnie, to

kontekstu działań partii Rzewuskiego ostatnio: Z. Hundert, Komputowe oddziały rodziny królewskiej w kampanii mołdawskiej 1686 roku w świetle rozkazów i sprawozdania sejmowego hetmana wielkiego koronnego Stanisława Jana Jabłonowskiego, [w:] D. Milewski (red.), Jarzmo Ligi Świętej? Jan III Sobieski i Rzeczpospolita w latach 1684-1696, Warszawa 2017, s. 179.

11 Ordynans jmp. podskarbiemu nadwornemu koronnemu, aby wziawszy pod komendę swoje wojsko niżej mianowane poszedt na pewna imprezę, obóz pod Huszem, 22 VII 1686, Biblioteka Zakładu Narodowego im. Ossolińskich we Wrocławiu [dalej: B. Ossol.], sygn. 250, k. 89v.

12 Pamiętnik Jana Stanisława Jabłonowskiego, wojewody ruskiego, wyd. A. Bielowski, Lwów 1862 , s. 63-64.

13 Patrz np. ordynans hetmana wielkiego koronnego Jana Sobieskiego: Zatrzymanie choragwi Wujakowskiego, [w:] Pisma do wieku i spraw Jana Sobieskiego, wyd. F. Kluczycki, t. I/2, Kraków 1881, s. 1037. 
i tak wystawiano rozkaz zawierający stosowną adnotację, np. nakazywano, aby odbiorca rozkazu ,poszedł na imprezę pewną, jako ustną odemnie bierze [...] informacyją"14. Ordynans rozpoczynał się od wskazania adresata. Niekiedy hetman wskazywał imiennie konkretnego oficera ${ }^{15}$, w innych przypadkach wskazywał tylko konkretne stanowisko pełnione przez adresata rozkazu ${ }^{16}$, a czasem nawet wprost przyznawał się do tego, że nie wie, który oficer aktualnie przebywa przy jednostce ${ }^{17}$. Dalej następowało wyliczenie podległych odbiorcy rozkazu jednostek i właściwa dyspozycja. Ordynans kończyło napomnienie, aby rozkaz wykonano „pod surowością artykułów wojskowych”18, albo wprost: „pod garłem”" Ordynanse dotyczyły nie tylko samych działań wojennych, ale także zachowania wojska na leżach zimowych ${ }^{20}$ czy też kwestii stricte dyscyplinarnych i związanych z wojskowym wymiarem sprawiedliwości ${ }^{21}$. Warto nadmienić, że w okresie wojny tureckiej 1683-1699 pod komendą hetmana Jabłonowskiego znalazło się także uznające władzę Rzeczypospolitej prawobrzeżne wojsko zaporoskie, dlatego też ordynanse hetmańskie kierowano również do pułków kozackich ${ }^{22}$. Rozkazy były wpisywane do kopiariuszy pism wychodzących z kancelarii hetmańskiej.

${ }^{14}$ Patrz np.: cytowany powyżej rozkaz dla Michała Floriana Rzewuskiego: Ordynans jmp. podskarbiemu nadwornemu koronnemu..., k. 89v; Ordynans jm. panu Czermińskiemu, porucznikowi choragwi pancernej jm. pana Wielohurskiego, kasztelanica wołyńskiego, aby wziawszy pod komendę swoję choragwie niżej mianowane poszedł na pewną imprezę, obóz pod Kamieńcem Podolskim, 25 VII 1689, Biblioteka XX. Czartoryskich w Krakowie [dalej: B. Czart.], sygn. 2679, s. 103.

${ }_{15}$ Ordynans jmp. podskarbiemu nadwornemu koronnemu..., k. 89v.: ,daję ten ordynans jmp. Michałowi Floryjanowi Rzewuskiemu, podskarbiemu nadwornemu koronnemu, chełmskiemu staroście, pułkownikowi wojsk JKM i Rzeczypospolitej”.

16 Ordynans choragwi pancernej jm. pana Pruszczyckiego do poddanych wyżgrodzkich przy Nowym Wiśniowcu osiadlych interesować się zabraniajacy, Lwów, 1 III 1692, B. Czart., sygn. 2699, k. 12: „daję ten ordynans jm. panu namiestnikowi chorągwi pancernej jm. pana [Jerzego] Pruszczyckiego, chorążęgo żytomirskiego".

${ }_{17}$ Ordynans jmp. majorowi regimentu dragońskiego Najjaśniejszego Króla Jmści, aby komenderowat ludzi rot kilka dla konwuju dziat i amunicyi idacych do Mariampola, Lwów, 24 VII 1692, ibidem, k. 51: „daję ten mój ordynans jm. panu majorowi, albo pod niebytność jego komendantowi regimentu dragońskiego Najjaśniejszego Króla Jmści w Żukowie stojącego".

18 Ibidem, k. 51.

19 Ordynans choragwi pancernej jm. pana Pruszczyckiego..., k. 12.

${ }^{20}$ Ordynans jmp. majorowi regimentu dragońskiego Najjaśniejszego Króla Jmści..., op.cit., k. 51.

${ }^{21}$ Ordynans do putków wszystkich, aby ichm. panowie porucznicy rewizja między soba zbiegłych żołdatów z blokady uczynili i onych pooddawali, obóz pod Boryszkowicami, 9 X 1692, ibidem, k. 84.

${ }^{22}$ Ordynans panu Iskrzyckiemu, pułkownikowi zaporoskiemu względem imania excessivorum ludzi jego i odprowadzenia do sądu mojego, Lwów, 2 III 1692, ibidem, k. 12v. Oddziały i pułki kozackie na służbie Rzeczypospolitej zaczęto obejmować regulacjami hetmańskimi już od lat 70. XVI w., jednakże wojska te posiadały odrębne sądownictwo i - przynajmniej do 1609 r. - prawo wojskowe, K. Łopatecki, Geneza kozackiego prawa i sądownictwa wojskowego: Z badań nad artykułami wojskowymi w Rzeczypospolitej szlacheckiej, [w:] M.R. Drozdowski, W. Walczak, K. Wiszowata-Walczak (red.), 
Gdy wojsko znajdowało się w obozie, hetman zwracał się do niego za pośrednictwem ordynansów. Do komunikacji ze wszystkimi oficerami i żołnierzami znajdującymi się na leżach zimowych służyły uniwersały hetmańskie kierowane do: „ichmościów panów pułkowników, oberszterów, rotmistrzów, poruczników, chorążych, namiestników i kompaniej w służbie wojsk JKM i Rzeczypospolitej polskiego i cudzoziemskiego zaciągu zostających"23. Przekazywanie uniwersałów hetmańskich pomiędzy poszczególnymi jednostkami regulowały artykuły wojskowe ${ }^{24}$. Ponadto sam hetman nakazywał publikować uniwersały w urzędach grodzkich i parafiach ${ }^{25}$. Tematyka uniwersałów najczęściej dotyczyła terminu rozpoczęcia kampanii, zachowania się żołnierzy na leżach zimowych i w czasie przemarszu na teatr działań wojennych, a także kwestii finansowych. Uniwersały, podobnie jak ordynanse, wpisywano do kopiariuszy hetmańskich ${ }^{26}$.

Istotnym instrumentem dowodzenia były zestawienia przydziałów jednostek do poszczególnych partii (zgrupowań) wojska i miejsc ich stacjonowania ${ }^{27}$. Sporządzano je najpewniej na użytek własny hetmana i również wpisywano do kopiariuszy kancelaryjnych. Zapewne część z nich była niezrealizowanymi nigdy w praktyce projektami ${ }^{28}$.

Hetmani w drugiej połowie XVII w. wpływali także w dość dużym stopniu na kształt organizacyjny wojska koronnego. Sama liczebność wojska, jak i poszczególnych rodzajów jednostek wchodzących w jego skład, była każdorazowo określana przez konstytucję sejmową uchwalaną jako tzw. scriptum ad archivum ${ }^{29}$,

Od Kijowa do Rzymu: Z dziejów stosunków Rzeczypospolitej ze Stolica Apostolska i Ukraina, Białystok 2012, s. 170-180; Т. Ковалець, «Конституиія Язловецького гетьмана з Бучача з козаками низовими запорозькими року Божого 1571»: Невідома постанова першої козацької комісії, „Іван Огієнко і сучасна наука та освіта: Серія історична та філологічна" 2015, Т. 11, s. 63-71.

${ }^{23}$ Uniwersat do wojska in visceribus Regni stojącego, aby się ściagato na partyje, sobie naznaczone pro 15 maii, Lwów, 20 III 1692, B. Czart., sygn. 2699, k. 29-32v.

${ }^{24}$ Artykuly wojenne hetmańskie autoritate sejmu aprobowane, Warszawa, 26 II 1609, [w:] S. Kutrzeba, Polskie ustawy i artykuły wojskowe, Kraków 1937, s. 182-183, art. 32. Por. K. Łopatecki, ,Disciplina militaris”, s. 200-201.

${ }^{25}$ Oblata litterarum illustris et magnifici Jabłonowski, obóz pod Uściem, 25 II 1685, Центральний державний історичний архів України, м. Львів [dalej: CDIAUL], f. 9, op. 1, spr. 448, s. 1841-1843 oblatowany w grodzie lwowskim, tudzież uniwersał hetmana wielkiego koronnego Stanisława Jabłonowskiego do oficerów i żołnierzy, Grodno, 24 III 1688, Центральний державний історичний архів України, м.Київ, f. 21, op. 1, spr. 232, s. nlb., pod datą 16 IV 1688, oblatowany w grodzie krzemienieckim.

${ }^{26}$ Uniwersat do wojska in visceribus Regni stojacego..., k. 29-32v.

${ }^{27} \mathrm{~Np}$. Konotacyja choragwi i regimentów wojska JKM i Rzeczypospolitej na partyje rozordynowanych pod różnymi komendami ex initiis kampaniej anni 1686, B. Ossol., sygn. 250, k. 140-143.

${ }^{28} \mathrm{~Np}$. Konotacyja choragwi na różne partyje rozkomenderowanych, [Lwów, XI 1692], B. Czart., sygn. 2699, k. 100-102.

${ }^{29}$ H. Olszewski, Sejm w dawnej Rzeczypospolitej. Ustrój i idee, t. I: Sejm Rzeczypospolitej epoki oligarchii (1652-1763). Prawo-praktyka - teoria-programy, Poznań 2002, s. 248-250. 
która - aby nie ujawniać zbyt szeroko jej postanowień - nie wchodziła w skład oficjalnie drukowanych konstytucji poszczególnych sejmów. Kolejny etap formowania armii, czyli podział uchwalonej sumy żołnierzy pomiędzy poszczególne jednostki, jak i wybór ich tytularnych bądź faktycznych rotmistrzów i oberszterów, zakładał współpracę hetmana i monarchy. Projekt komputu wojska zasadniczo układał hetman, ale jedynie król miał prawo wydawania listów przypowiednich - dokumentów upoważniających do formowania jednostek przeznaczonych do służby w wojsku koronnym ${ }^{30}$. Hetman decydował także o strukturze pułków jazdy zaciągu narodowego ${ }^{31}$. Pozostałością tego aspektu działalności hetmańskiej są obecne niemal w niezliczonych ilościach w archiwaliach po hetmanie Stanisławie Jabłonowskim komputy bądź projekty komputów wojska koronnego, obejmujące zarówno całość armii, jak też tylko oddziały poszczególnych autoramentów. Standardową praktyką za hetmaństwa Jabłonowskiego było sporządzanie komputu przynajmniej raz do roku - jesienią przy okazji obrad komisji hibernowej ${ }^{32}$, wtedy także dokonywano stosownych zmian organizacyjnych - zmian etatowych liczebności jednostek.

Za tworzenie akt hetmańskich odpowiadała podporządkowana mu kancelaria ${ }^{33}$. Nieliczne informacje źródłowe, jakie zachowały się na temat jej funkcji i organizacji za hetmaństwa Jabłonowskiego, zostały wyczerpująco wykorzysta-

${ }^{30} \mathrm{Na}$ temat wydawania listów przypowiednich w pierwszej połowie XVII w.: P. Gawron, op.cit., s. 89-96, 117-118. Na temat sporów Jana III z ks. hetmanem Dymitrem Wiśniowieckim o kształt zredukowanego komputu wojska koronnego po 1677 r.: Z. Hundert, Pozycja Jana III $w$ wojsku koronnym $w$ latach 1674-1683: Utrzymanie czy też utrata wplywów wypracowanych w czasie sprawowania godności hetmańskiej, [w:] D. Milewski (red.), Król Jan III Sobieski i Rzeczpospolita w latach 1674-1683, Warszawa 2016, s. 133-134.

31 Świadczy o tym obietnica stworzenia nowego pułku jazdy, którą hetman Stanisław Jabłonowski złożył wojewodzie bełskiemu Adamowi Mikołajowi Sieniawskiemu, S. Jabłonowski do A.M. Sieniawskiego, Lwów, 25 [VI albo VII] 1698, B. Czart., sygn. 5839, s. 245.

${ }^{32}$ Przykład takiego komputu: Komput wojska JKM i Rzeczypospolitej na hiberne in anno 1686, B. Ossol., sygn. 250, k. 148-151v.

33 Warto podkreślić, że hetmani będący jednocześnie magnatami każdorazowo podejmowali decyzję o bardziej lub mniej rozdzielonych kompetencjach kancelarii publicznej i prywatnej. Przykładowo takie kancelarie posiadał hetman wielki koronny Jan Klemens Branicki. Kancelaria służbowa dzieliła się na hetmańską i wojskową, czyli związaną z funkcjonowaniem poszczególnych oddziałów w garnizonowym Białymstoku. Kancelaria prywatna składała się z części cywilnej (prowadzoną przez dwóch sekretarzy - polskiej i cudzoziemskiej ekspedycji) oraz osobistej. K. Łopatecki, W. Walczak, Wstęp, [w:] K. Łopatecki, W. Walczak (oprac.), Pałac Branickich w Białymstoku, t. I: Inwentarze z XVII i XVIII stulecia, cz. 1, Białystok 2012, s. 113-114; T. Zielińska, Archiwa wielkich rodów Rzeczypospolitej dziedzictwem narodów Europy Środkowo-Wschodniej, „Archiwista Polski" 1999, t. 2, s. 33-40; eadem, Klientela w otoczeniu Jana Klemensa Branickiego kasztelana krakowskiego i hetmana wielkiego koronnego około XVIII wieku, [w:] E. Dubas-Urwanowicz, J. Urwanowicz (red.), Patron i dwór. Magnateria Rzeczypospolitej w XVI-XVIII wieku, Warszawa 2006, s. 211-219. 
ne przez Marka Wagnera ${ }^{34}$. Niemniej jednak warto zwrócić baczniejszą uwagę na osoby pisarzy wojskowych - przełożonych kancelarii hetmańskiej. Byli oni powoływani na swoje stanowisko najpewniej przez hetmanów i funkcjonowali na podobnych zasadach jak np. pisarze marszałkowscy ${ }^{35}$ - jako aparat pomocniczy najważniejszych urzędników centralnych. Ich faktyczne znaczenie wśród elit militarnych Korony mogło być jednak, jak wykażemy, bardzo istotne.

Najpóźniej od 1691 r. funkcję pisarza wojskowego pełnił miecznik kaliski, a później chorąży wołyński i starosta włodzimierski Wojciech Stanisław Czacki ${ }^{36}$. Nie wiadomo, kiedy dokładnie ten urodzony prawdopodobnie w $1655 \mathrm{r}^{37}$ szlachcic wielkopolski zaciągnął się do służby w wojsku koronnym. O. Kasper Niesiecki SJ podawał, że odznaczył się on w czasie bitwy pod Chocimiem (1673), czego jednak nie potwierdzają inne źródła ${ }^{38}$. Podobnie niskiej wiarygodności źródło stwierdza, że brał udział w wyprawie wiedeńskiej $1683 \mathrm{r} .{ }^{39} \mathrm{Na}$ pewno był towarzyszem husarskim hetmana Stanisława Jabłonowskiego wiosną 1685 r., kiedy to, oprócz własnego, wystawił poczet husarski w zamian za świeżo dopuszczonego do indygenatu Jana Wołczyńskiego ${ }^{40}$. W 1687 r. został odnotowany jako chorąży

${ }^{34}$ M. Wagner, Prawa i obowiązi oficerów armii koronnej w drugiej połowie XVII w.: Ze studiów nad rozwojem prawa wojskowego w dawnej Rzeczypospolitej, „Studia i Materiały do Historii Wojskowości" 1994, t. XXXVI, s. 40-50; idem, Przemiany organizacyjne armii koronnej końca XVII wieku: Wybrane problemy wojskowości polskiej w okresie hetmaństwa Stanisława Jabłonowskiego, [w:] Z. Karpus, W. Rezmer (red.), Od armii komputowej do narodowej (XVI-XX w.), Toruń 1998, s. 109-110.

${ }^{35} \mathrm{~K}$. Wiśniewski, Urząd marszałkowski koronny w bezkrólewiach XVII-XVIII wieku (16321736), Warszawa 2015, s. 316-315.

${ }^{36}$ W 1691 r. na początku obrad Trybunału Skarbowego Czacki składał przysięgę, że nie ujawni tajemnic sądu - co było czynnością obligatoryjną dla personelu pomocniczego Trybunału. Generosi Czacki, ensiferi platinatus Calisiensis iuramentum, [Lwów], 8 I 1691, CDIAUL, f. 10, op. 1, spr. 86, s. 7. W tym samym roku komisja hibernowa przyznała mu $1500 \mathrm{zł}$ zwyczajowego wynagrodzenia należnego osobom pełniącym rozmaite funkcje administracyjne związane z pełnionymi urzędami, np. instygatorowi koronnemu, sędziemu wojskowemu, generałowi-audytorowi, itp., Hiberna wojsku in anno 1691, [Lwów], 29 XI 1691, ibidem, spr. 115, s. 348. Czacki doczekał się własnego biogramu, M. Wagner, Słownik biograficzny oficerów polskich drugiej połowy XVII wieku, t. I, Oświęcim 2013, s. 102, aczkolwiek ten nie uwzględnia wielu faktów z życiorysu starosty włodzimierskiego.

37 E. Danowska, Dzieje rodziny Czackich na Wotyniu do XVIII wieku, „Przegląd Wschodnioeuropejski" 2015, t. VI/2, s. 13.

${ }^{38}$ K. Niesiecki, Herbarz polski, wyd. J.N. Bobrowicz, t. XI, Lipsk 1845, s. 83-84. Konstytucji, na którą powoływał się Niesiecki, brak w Volumina legum.

39 Spis rycerstwa polskiego walczacego z Janem III pod Wiedniem oraz szyk bojowy wojsk polskich i sprzymierzonych dnia 12 września 1683 r., wyd. [B. Twardowski], Poznań 1883, s. 8.

${ }^{40}$ Atestacja JMP Wojciechowi Czackiemu towarzyszowi choragwi mojej usarskiej, iż stawit poczet zupetny za JmP Wołczyńskiego na tej kampaniej, Lwów, 6 XI 1685, B. Ossol., sygn. 250, k. 4-4v. Konstytucja sejmu 1685 r. zobowiązywała wszystkich nobilitowanych i dopuszczonych do 
chorągwi husarskiej hetmana wielkiego ${ }^{41}$. To stanowisko objął po tym, jak w tym samym roku dotychczasowy chorąży, Wacław Iskra, został porucznikiem husarskim późniejszego podkomorzego koronnego Kazimierza Ludwika Bielińskiego $^{42}$. Kolejny awans przyszedł najpewniej latem 1693 r. - Czacki uzyskał rotmistrzostwo stukonnej chorągwi pancernej po zmarłym biskupie chełmińskim Kazimierzu Opalińskim ${ }^{43}$. Wreszcie w 1694 r. został porucznikiem chorągwi pancernej hetmana Jabłonowskiego, prawdopodobnie po odejściu z aktywnej służby wojskowej jej dotychczasowego dowódcy płka Prokopa Jana Granowskiego, starosty żytomierskiego ${ }^{44}$. Dodatkowo, zapewne jesienią 1696 r., uzyskał on szefostwo stukonnej frejkompanii dragońskiej po swoim zmarłym teściu - kasztelanie wołyńskim Stefanie Zahorowskim ${ }^{45}$. Starosta włodzimierski zmarł we wrześniu 1699 r. ${ }^{46}$ Jego chorągiew pancerną (zredukowaną po przejściu wojska na etat pokojowy do 60 koni) przejął wojewoda kijowski, generał artylerii koronnej Marcin $\mathrm{Kactski}^{47}$.

Czacki sprawował pełny nadzór nad kancelarią i właśnie on zajmował się szczegółowym opracowaniem treści wystawianych przez hetmana dokumentów. W grudniu 1695 r. to z nim o. Tomasz Perkowicz SJ, lwowski rezydent podskarbiny wielkiej koronnej Anny z Gnińskich Zamoyskiej ustalał dokładny kształt het-

indygenatu od 1653 r. do wystawienia i utrzymywania własnym sumptem pocztu husarskiego przez trzy kampanie, Subsidium usarskiej milicyi z nowej szlachty, VL, t. V, s. 348-349.

${ }^{41}$ Generosus Czacki nomine Illustris et Magnifici Leszczyński eandem commissionem [i.e. hybernalem] et notarium quartae thesauri Regni quietat, [Lwów], 29 XII 1687, CDIAUL, f. 9, op. 1, spr. 170, s. 2099-2100.

${ }^{2}$ J.J. Sowa, ,Dysponuję krwawa pracę moję”: Testamenty oficerów wojska koronnego z ksiag grodzkich lwowskich z lat 80. XVII wieku, „Biblioteka Epoki Nowożytnej” 2016, t. 5, s. 589.

${ }^{43}$ Idem, ,Ludzie niezwalczeni”: Rejestry choragwi jazdy autoramentu narodowego w Okopach św. Trójcy, 1693-1695, [w:] Studia nad staropolska sztuka wojenną, t. II, red. Z. Hundert, Oświęcim 2013, s. 275.

${ }^{44}$ Czacki był na pewno porucznikiem pancernym Jabłonowskiego jesienią 1695 r.; Actus komisjej hibernowej lwowskiej za szczęśliwym powrotem z kampaniej Jaśnie Oświeconego JM Pana Kasztelana Krakowskiego, Hetmana Wielkiego Koronnego in anno Domini 1695 odprawionej, [Lwów 1695], B. Czart., sygn. 2524, s. 54. Granowski (informacja o poruczeństwie chorągwi Jabłonowskiego na podstawie, Ordynans JMP Granowskiemu, staroście żytomierskiemu, porucznikowi choragwi mojej pancernej, aby wziąwzy pod komendę swoję choragwie niżej mianowane poszedt z nimi na pewna imprezę, obóz koło Łopusznej Doliny, 31 VIII 1686, B. Czart., sygn. 250, k. 92v.) nie figuruje w rejestrze largicji za 1694 r., więc najpewniej wtedy odszedł ze służby.

${ }^{45}$ Ptaca wojska Rzeczypospolitej polskiego i cudzoziemskiego zaciagu ad proportionem ostatnich deklaracyi sejmu anni 1690 na ćwierci numero 8 danych, in duplo porachowanych regulujaca się, a przez Trybunat Skarbowy Lwowski anni 1697 na województwa i ziemie ordynowana, AGAD, Archiwum Skarbu Koronnego [dalej: ASK], dz. 86, sygn. 74, s. 225.

${ }^{46}$ Urzędnicy wołyńscy XIV-XVIII wieku: Spisy, oprac. M. Wolski, Kórnik 2007, s. 123.

47 Actus komisyjej hibernowej anno millesimo sexcentesimo nonagesimo nono we Lwowie odprawionej, Lwów, 5 XI 1699, B. Czart., sygn. 2673, t. 2, s. 42. 
mańskich uniwersałów ochronnych dla jej dóbr ${ }^{48}$. Szczególnie intensywnie miał pracować podczas obrad Trybunału Skarbowego i komisji hibernowej, o czym świadczą przyznawane mu wynagrodzenia. Pisarz wojskowy odgrywał bardzo ważną rolę przy rozdziale largicji - specjalnych wynagrodzeń przyznawanych rokrocznie przez hetmana wyższym oficerom wojska koronnego ze skarbu hibernowego ${ }^{49}$. Ponadto do obowiązków starosty włodzimierskiego należało odbieranie ze skarbu koronnego w imieniu niektórych posesorów rekompensat przyznawanych przez komisję hibernową za kwaterunki żołnierzy w ich dobrach. Czacki bowiem odbierał takie rekompensaty po raz pierwszy już w 1687 r., być może zatem już wówczas był przełożonym kancelarii hetmańskiej ${ }^{50}$.

Pomocą w karierze wojskowej mogła być dla starosty włodzimierskiego jego korzystna sytuacja finansowa. Świadczą o niej nie tylko wspomniane już wystawienie pocztu husarskiego za Jana Wołczyńskiego, ale też udzielane pożyczki. W 1686 r. pożyczył on Janowi Wojciechowi Rajeckiemu, kapitanowi regimentu pieszego miecznika koronnego Michała Warszyckiego 4000 zl, a około 1690 r. przekazał hetmanowi Jabłonowskiemu 40 tys. zł pod zastaw wsi Leszczyn w ziemi lwowskiej ${ }^{51}$. Za swoją pracę pisarz wojskowy był zresztą sowicie wynagradzany z publicznych środków. Trybunał Skarbowy w $1691 \mathrm{r}$. przyznał mu 19550 zł potrąconych z zasług wojska autoramentu cudzoziemskiego $^{52}$. Rok później w czasie obrad Trybunału uzyskał 16780 zł³. Z kolei

48 T. Perkowicz do A. Zamoyskiej, Lwów, 29 XII 1695, AGAD, Archiwum Zamoyskich [dalej: AZ], sygn. 1380, s. 172-175.

${ }_{49}$ Dziennik Jana Stanisława Jabłonowskiego, cz. I, (R. 1694-1695), wyd. W. Chomętowski, Warszawa 1865, s. 165.

${ }^{50} \mathrm{~Np}$. Generosus Czacki nomine Illustris et Magnifici Leszczyński eandem commissionem [i.e. hybernalem] et notarium quartae thesauri Regni quietat..., s. 2099-2100; asygnacja S. Jabłonowskiego na wypłatę rekompensaty Hieronimowi Lanckorońskiemu, podkomorzemu podolskiemu, Lwów, 24 XI 1695, AGAD, ASK., dz. VI, sygn. 25, f. 35.

${ }^{51}$ Generosus Czacki Generosum Rajecki quietat, [Lwów], 15 I 1687, CDIAUL, f. 9, op. 1, spr. 170, s. 206-207; Generosus Czacki Illustrem et Magnificum Palatinum Russiae, Supremum Exercituum Ducem de summis binis quietat, [Lwów], 19 I 1690, ibidem, spr. 173, s. 325.

52 Podziat wojska JKM i Rzeczypospolitej na Trybunale Skarbowym Lwowskim anni 1691 vigore deklaracyi na sejmie przeszlym 1690 anni danych do ćwierci numero 12 a die 1 Februarii 1687 anni zaczynających się, a kończacych die ultima Januarii 1690 anni redukowany $i$ spisany, Lwów, 19 II 1691, AGAD, ASK, dz. 86, sygn. 71, s. 152, 182, 188. Dodatkowo Czacki uzyskał także 8827 zł ze środków należnych wojsku za tzw. ćwierć żórawieńską (ćwierć februarjuszową czyli lutową 1677 r.). Najpewniej była to jednak jakaś forma spłaty kolejnej pożyczki udzielonej przez Czackiego hetmanowi Jabłonowskiemu bądź któremuś z innych oficerów wojska koronnego, ibidem, s. 241.

${ }^{53}$ Płaca wojsku JKMci i Rzeczypospolitej polskiego i cudzoziemskiego zaciagu ad proportionem medietatis deklaracyi sejmu anni 1690 na ćwierci numero 8 danych przez Trybunat Skarbowy Radomski anni 1692 na województwa i ziemie ordynowana, Radom, 19 V 1692, AGAD, ASK, dz. 86, sygn. 73, s. 106. 
w 1697 r. otrzymał 11775 z t54 $^{5}$. Zapewne cześć tych środków miała pokryć koszty funkcjonowania kancelarii hetmańskiej. Czackiego wynagradzały także komisje hibernowe - w latach 1691-1695 przyznawano mu regularnie po $1500 \mathrm{zk}$, a w 1697 r. 3000 zł. To wynikało z faktu, iż Czacki pełnił swoją funkcję zarówno podczas dystrybuty hiberny, jak i przy komisji do traktatów ze skonfederowanym wojskiem ${ }^{55}$. Oprócz tego starosta włodzimierski otrzymywał także regularnie largicje. W latach 1690-1693 była to kwota $2000 \mathrm{zł} \mathrm{(czyli} \mathrm{tyle,} \mathrm{ile} \mathrm{dostawał}$ np. porucznik królewskiej chorągwi pancernej czy pisarz polny koronny), a od 1694 r. 3000 zł (standardowa kwota przyznawana porucznikom hetmańskich chorągwi pancernych i chorągwi husarskich ważniejszych magnatów $)^{56}$.

Czacki był także wybierany na kołach wojskowych jako reprezentant żołnie$\mathrm{rzy}^{57}$. Z ich ramienia pełnił funkcję jednego z komisarzy na Trybunale Skarbowym 1692 r. ${ }^{58}$ Co najmniej dwukrotnie wybierano go też dystrybutorem żołnierskim na komisjach hibernowych w 1695 i 1699 r. (w tym drugim przypadku nie objął funkcji, ponieważ zmarł $)^{59}$. To również wiązało się z uzyskaniem stosownych traktamentów.

${ }^{54}$ Ptaca wojska Rzeczypospolitej polskiego i cudzoziemskiego zaciagu ad proportionem ostatnich deklaracyi sejmu anni $1690 \ldots$, s. 281, 392-393.

${ }_{55}$ Hiberna wojsku in anno 1691 ..., s. 348; Hiberna wojsku in anno 1692, Lwów, 13 XI 1692, CDIAUL, f. 10, op. 1, spr. 115, s. 395; Hiberna na wojsko in anno 1693, Lwów, 30 XI 1693, ibidem, s. 437; Hiberna wojsku in anno 1694, Lwów, 17 XI 1694, ibidem, s. 477; Hiberna wojsku in anno 1695, [Lwów], 24 XI 1695, ibidem, s. 545; Dyspozycja hiberny anni 1696 przez komisja do traktowania $z$ wojskiem skonfederowanym ex limitatione reasumowana i z Trybunatem Skarbowem Lwowskiem coninuctam po niedosztym traktatcie samborskim uczyniona we Lwowie in anno 1697, Lwów, 23 III 1697, CDIAUL, f. 10, op. 1, spr. 115, s. 280.

56 Regestr largitionum pro anno 1690, [Lwów], 24 XI 1690, ibidem, spr. 115, s. 299-300; Regestr largitionum pro anno 1691, [Lwów], 29 XI 1691, s. 351; Regestr largitionum pro anno 1692, [Lwów], 13 XI 1692, ibidem, s. 397; Largicyje wojsku z komisyi hibernowej lwowskiej anni 1693, [Lwów], 30 XI 1693, ibidem, s. 439; Largicyje wojsku na hibernie in anno 1694, [Lwów], 17 XI 1694, ibidem, s. 479; Largicje wojsku na hibernie in anno 1695, [Lwów], 24 XI 1695, ibidem, s. 549.

${ }^{57} \mathrm{O}$ organizacji i kompetencjach kół wojskowych: J. Urwanowicz, Wojskowe „sejmiki”. Koła w wojsku Rzeczypospolitej XVI-XVIII wieku, Białystok 1996; idem, Zgromadzenia wojskowe a instytucje parlamentarne w Rzeczypospolitej XVI-XVIII wieku: Relacje, aspiracje, analogie, [w:] A. Stroynowski (red.), Kultura parlamentarna epoki staropolskiej, Warszawa 2013, s. 47-59; K. Łopatecki, Udziat ,, sejmików” wojskowych przy tworzeniu i ogłaszaniu artykułów wojskowych w XVI i XVII stuleciu, „Miscellanea Historico-Iuridica” 2013, 12, s. 75-102; T. Ciesielski, Koła wojskowe w partiach i choragwiach w wojsku koronnym w latach 1717-1763, [w:] W. Kaczorowski (red.), Studia historyczno-prawne: Księga pamiątkowa poświęcona pamięci Profesora Jana Seredyki, Opole 2008, s. 107-120.

${ }_{58}$ Płaca wojsku JKMci i Rzeczypospolitej polskiego i cudzoziemskiego zaciagu ad proportionem medietatis deklaracyi sejmu anni 1690..., s. 93.

59 S. Jabłonowski do Jana III, Lwów, 26 X 1695, Нацыянальны гістарычны архіў Беларусі, Мінск [dalej: NGAB], f. 695, vop. 1, spr. 99, k. 79; Actus komisyjej hibernowej anno millesimo sexcentesimo nonagesimo nono..., s. 180. 
Hetman Jabłonowski korzystał z usług starosty włodzimierskiego również w celach prywatnych - latem 1694 r. Czacki reprezentował swojego pryncypała przed Trybunałem Koronnym ${ }^{60}$, szczycił się bowiem nabytą w młodości dobrą znajomością prawa ${ }^{61}$. Z poparciem hetmańskim był także wybierany posłem na sejm m.in. w $1694 \mathrm{r}^{62}$ Wiadomo, że pozostawał w przyjacielskich stosunkach z synem hetmana - wojewodą wołyńskim, a potem ruskim Janem Stanisławem Jabłonowskim $^{63}$.

Wysoka pozycja starosty włodzimierskiego jako swego rodzaju szarej eminencji w środowisku oficerskim z jednej strony dopomagała mu w pokonywaniu kolejnych szczebli awansu społecznego i majątkowego - to zapewne jej w dużej mierze Czacki zawdzięczał bardzo korzystny ożenek z Katarzyną z Zahorowskich, córką kasztelana wołyńskiego i rotmistrza JKM Stefana ${ }^{64}$. Z drugiej jednak strony musiała budzić zawiść części elit wojskowych. Jako jeden z najbardziej zaufanych współpracowników kasztelana krakowskiego Czacki stawał się także dość wygodnym celem ataków wymierzonych pośrednio w samego hetmana. W październiku 1695 r. hetman polny koronny, wojewoda krakowski Szczęsny Potocki narzekał: ,że Pan Czacki chorągwie prowadząc jego w namiecie stojącego nie dojrzał i czapki nie uchylił, o to się wielce skarżył, jakby to nasza [Jabłonowskich] namowa była" ${ }^{65}$. Zaś w listopadzie 1695 r. przed sądem hetmańskim został on oskarżony przez pułkownika Andrzeja Ścibora Chełmskiego o malwersację 12000 zł, a w grudniu tego roku pułkownik Stefan Aleksander Potocki, łowczy koronny, dopominał się u Czackiego o largicję dla porucznika swojej chorągwi. Zarzucał mu jednocześnie, że „drudzy na enemy biorą panem merentium”"66. Wreszcie na początku 1696 r. pisarz wojskowy stał się obiektem zjadliwego listu, a właściwie paszkwilu Michała Potockiego, starosty krasnostawskiego, syna hetmana polnego. Zdaniem o. Perkowicza: „list to był nie inkaustem, ale żółcią pisany, czci nie zostawujący a z okazyi niedoszłej largicyi” i dalej informował: „chciał Pan Czacki wzajemnie takowym stylem pociągnąć pióra, ale mu Państwo nasze [Jabłonowscy] ręki przytrzymało, mądrze tego dociekłszy, że ta była prowokatora intencja, aby w odpowiadającym liście na dyshonor teraźniejszy, w Trybunale funkcjej cokolwiek naciągnąwszy ${ }^{67}$, pozwami i grzywnami okryć, a tak

${ }^{60}$ Dziennik Jana Stanisława Jabłonowskiego..., s. 28.

${ }^{61}$ Respons JMP Czackiego starosty włodzimierskiego na list JM Pana Starosty Krasnostawskiego, [po 5 II 1696], Biblioteka Narodowa w Warszawie, sygn. 9085, s. 223.

${ }_{62}$ Dziennik Jana Stanisława Jabłonowskiego..., s. 52.

${ }_{63}$ Ibidem, s. 87-88.

${ }^{64}$ E. Danowska, Dzieje rodziny Czackich..., s. 14.

65 T. Perkowicz do A. Zamoyskiej, Podkamień, 12 X 1695, AGAD, AZ, sygn. 1380, s. 163.

${ }^{66}$ Dziennik Jana Stanistawa Jabłonowskiego..., s. 151-165.

${ }^{67}$ Potocki sprawował wówczas funkcję marszałka Trybunału Koronnego. 
sobie nadgrodzić largicyi. Więc wolał Pan Czacki rzeczą odpowiedzieć złożeniem hetmańskiego pióra, za które publicznie przy dokończeniu komisyi [hibernowej] już podziękował" ${ }^{\prime 6}$. Ostatecznie stało się jednak inaczej - starosta włodzimierski opublikował respons na zarzuty Potockiego i zdecydował się pozostać na stanowisku pisarza wojskowego ${ }^{69}$.

Kolejne zarzuty przeciw Czackiemu wytoczyli jesienią 1696 r. skonfederowani żołnierze. Tym razem pisarza wojskowego oskarżono o malwersację rekompensat dla posesorów (m.in. dla ks. Janusza i Michała Serwacego Wiśniowieckich) ${ }^{70}$. Determinacja związkowych w tej sprawie była na tyle duża, że hetman Jabłonowski w traktacie samborskim zawartym z konfederatami zobowiązał się osądzić sprawę Czackiego na początku najbliższej komisji skarbowo-wojskowej ${ }^{71}$. Nie wiadomo, czy doszło do rozprawy, nie przeszkodziło to jednak staroście włodzimierskiemu w dalszym sprawowaniu jego funkcji.

Następcą Wojciecha Stanisława Czackiego na stanowisku pisarza wojskowego został najpewniej Szymon Franciszek Pułaski. Jego życiorys był już przedmiotem zainteresowania historiografii ${ }^{72}$. Kluczowy jest fakt, że podobnie jak dla Czackiego „hetmańskie pióro” było dla niego przepustką do awansu majątkowego i społecznego. Tak duże znaczenie (w przypadku starosty włodzimierskiego mierzone chociażby skalą i zajadłością krytyki) pisarzy wojskowych jest pośrednim, ale bardzo istotnym wskaźnikiem, jaką wagę miała dokumentacja działalności hetmanów wielkich koronnych. W tym świetle nie można uznawać pisarzy wojskowych jedynie za osobistych sekretarzy hetmana, ale za ważne ogniwo w administrowaniu siłami zbrojnymi Korony.

Pisarze wojskowi odpowiadali nie tylko za tworzenie dokumentacji, ale także za jej gromadzenie. Znamienny jest pod tym względem los sporej spuścizny aktowej po Jabłonowskim - za pośrednictwem wzmiankowanego powyżej Szymona

${ }^{68}$ T. Perkowicz do A. Zamoyskiej, Mościska, 5 II 1696, AGAD, AZ, sygn. 1380, s. 188.

${ }^{69}$ Respons JMP Czackiego..., s. 219-233.

${ }^{70}$ Instrukcyja IchMciom Panom Komisarzom od wojska skonfederowanego do Jaśnie Wielmożnych IchMciów Panów Komisarzów z konfederacyi konwokacyjonalnej warszawskiej od całej Rzeptej na umówienie wojska interesów przysłanym JegoMci Panu Konstantemu Zawadzkiemu, [Adamowi] na Drohojowie Drohojowskiemu stolnikowi ziemie buskiej [powinno być: bielskiej], Michałowi Poradowskiemu, Andrzejowi Goskowskiemu, Stanisławowi Krzeszowi ordynowanym, obóz pod Dawidowem, 29 X 1696, CDIAUL, f. 10, op. 1, spr. 87, s. 11-12.

${ }^{71}$ Oblata tractatus samboriensis, Sambor, 30 IV 1697, ibidem, s. 297.

72 A.K. Link-Lenczowski, Pułaski Szymon Franciszek, „Polski Słownik Biograficzny” 1986, t. XXIX, s. 397-399; J.J. Sowa, Formularz kancelarii hetmańskiej z przetomu XVII i XVIII w.: Processus sąów hetmańskich... Szymona Franciszka Pułaskiego, „Czasopismo Prawno-Historyczne” 2011, t. LXIII, z. 2, s. 305-327. Marek Wagner wymienia jako kolejnego pisarza wojskowego w latach 1700-1702 niejakiego Czachurskiego, ale nie podaje podstawy źródłowej, M. Wagner, Stanisław Jabłonowski..., t. 2, s. 140. 
Franciszka Pułaskiego trafiła ona do archiwum kolejnych hetmanów, którym służył Pułaski - Hieronima Augustyna Lubomirskiego i Adama Mikołaja Sieniawskiego (od którego pisarz wojskowy domagał się bezskutecznie zwrotu części $\mathrm{akt})^{73}$. Ten ostatni przechowywał dokumenty powstałe za czasów Jabłonowskiego razem z własnymi aktami wydawanymi na mocy prerogatyw hetmańskich ${ }^{74}$. Dla mającego dość mizerne doświadczenie wojskowe Sieniawskiego było to ważne źródło wiedzy na temat praktyki dowodzenia wojskiem koronnym - na bazie doświadczeń Jabłonowskiego mógł przeprowadzać własne reformy w wojsku koronnym ${ }^{75}$.

Długotrwałe wojny toczone przez państwa europejskie w okresie wczesnonowożytnym sprzyjały rozwojowi archiwów wojskowych, jak i ogólnie bardziej biurokratycznych form administrowania siłami zbrojnymi ${ }^{76}$. Praktyka archiwalna bywała różna w różnych państwach i okresach - zdarzało się jednak, że dokumenty najbardziej związane z codzienną praktyką funkcjonowania armii (jak np. imienne rolle popisowe), choć stworzone na podstawie udzielonej oficerowi przez państwo władzy, często nie trafiały później do państwowych skarbców, a pozostawały w rękach dowódców, najbardziej zainteresowanych zdobyciem zawartej w nich wiedzy ${ }^{77}$. Siłą rzeczy rosła też rola wojskowych biurokratów - korpusu urzędników odpowiedzialnych za nadzór nad opłaceniem, zaopatrzeniem, dyscyplinowaniem żołnierzy i, last but not least, dokumentowaniem tych wszystkich poczynań na piśmie ${ }^{78}$. Co ważne, coraz częściej funkcje te nie były pełnione przez oficerów, ale przez cywilów - stanowiąc namiastkę cywilnej kontroli nad wojskiem.

W państwie polsko-litewskim zachodziły podobne co do istoty procesy, jak w innych wczesnonowożytnych państwach europejskich, aczkolwiek ich ska-

${ }^{73}$ A.K. Link-Lenczowski, op.cit., s. 397-399.

${ }^{74}$ Patrz aneks.

75 Por. M. Nagielski, Upadek staropolskiej sztuki wojennej $w$ dobie wielkiej wojny pótnocnej, [w:] J. Muszyńska (red.), Rzeczpospolita $w$ dobie wielkiej wojny pótnocnej, Kielce 2001, s. 11-43; J. Ronikier, Hetman Adam Sieniawski i jego regimentarze. Studium z historii mentalności szlachty polskiej 1706-1725, Kraków 1992, s. 135-145.

${ }^{76}$ Zjawisko to dobrze przedstawił ostatnio Andrea Guidi na przykładzie archiwów florenckich w dobie wojen włoskich w pierwszej połowie XVI w., A. Guidi, The Florentine Archives in Transition: Government, Warfare and Communication (1289-1530 ca.), "European History Quarterly" 2016, vol. 46/3, s. 458-479.

${ }^{77} \mathrm{~W}$ tym przypadku znów zjawisko to jest dobrze widoczne na przykładzie renesansowej Florencji: A. Guidi, 'Per peli e per segni'. Muster rolls, lists and notes: practical military records relating to the last Florentine ordinanze and militia, from Machiavelli to the fall of the Republic (1506-30), "Historical Research" 2016, vol. 89, s. 673-686.

${ }^{78}$ Klasyczne już studium na ten temat: G. Rowlands, The Dynastic State and the Army under Louis XIV: Royal Service and Private Interest, 1661-1701, Cambridge (UK) 2002, zwłaszcza cz. I (s. 27-149). 
la i tempo w niektórych aspektach dość znacząco odbiegały od wzorcowych przykładów z zachodniej Europy. Akta pozostawione przez urzędników kancelaryjnych hetmana Jabłonowskiego pokazują jednakże, że pod koniec XVII w. w Koronie przywiązywano dość dużą wagę do należytego udokumentowania czynności podejmowanych przez samego hetmana, jak i inne organy administracji wojskowej. Ich lektura dawała dość dokładny obraz funkcjonowania wojska koronnego. Kiedy zatem np. Jabłonowski pisał do Jana III jesienią 1695 r., że nie rozlokował na leżach zimowych na Polesiu Kijowskim żadnych jednostek, podczas gdy w latach wcześniejszych stacjonowało tam regularnie po kilkanaście chorągwi ${ }^{79}$, mógł swoje twierdzenia poprzeć szczegółowymi zestawieniami miejsc, w których kwaterowało wojsko koronne, przygotowywanymi w kancelarii hetmańskiej ${ }^{80}$.

Równolegle zyskiwali też na znaczeniu wojskowi urzędnicy. Wprawdzie zarówno Czacki, jak i Pułaski oficjalnie posiadali stopnie oficerskie, ale nie ulega wątpliwości, że swoją wysoką pozycję i awans społeczny wywalczyli raczej piórem niż szablą - o ich przewagach na polu bitwy źródła bowiem milczą. Oprócz nich zresztą w czynności administracyjne związane z wojskiem, czy to na poziomie komisji hibernowych i Trybunału Skarbowego, czy na poziomie sejmikowym było zaangażowane też spore grono rzeczywistych cywilów. Wydaje się zatem, że ważnym postulatem dla przyszłej historiografii jest kontynuowanie badań nad wojskowymi i związanymi z wojskiem administratorami, zwłaszcza w szerokim kontekście porównawczym.

\section{ANEKS}

Archiwum hetmańskie Stanisława Jabłonowskiego w ramach archiwum hetmańskiego Adama Mikołaja Sieniawskiego na podstawie Sumariusza aktów różnych hetmańskich, wojskowych, sądów, ordynansów, komisyi hibernowych lwowskich, luckich, radomskich etc. i róznych dziejów wojennych sub interregno post olim Serenissimum Joannem III, regem Poloniae et sub hostico circa electionem Serenissimi olim Regis Augusti II etc. za walecznej butawy śp. Jaśnie Oświeconego JM Pana Adama Mikotaja z Granowa Sieniawskiego, hrabi na Szkłowie i Myszy, kasztelana krakowskiego, hetmana wielkiego koronnego, lwowskiego generalnego, rohatyńskiego, lubaczowskiego, piaseczyńskiego, stryjskiego starosty ab anno 1696 aż ad fata eiusdem in anno 1726 dziejących się autorstwa Jana Józefa Witoszyńskiego ${ }^{81}$, [przed 31 X 1762], B. Czart., sygn. 2470, s. 1-8:

79 S. Jabłonowski do Jana III, Lwów, 9 XI 1695, NGAB, f. 695, op. 1, spr. 99, k. 83.

80 Przykład y takich zestawień za lata 1697-1701, B. Czart, sygn. 2603 (cała jednostka).

${ }^{81}$ Sumariusz Jana Józefa Witoszyńskiego, archiwisty na służbie najpierw Adama Mikołaja Sieniawskiego, a potem Augusta Aleksandra Czartoryskiego, wojewody ruskiego (na jego temat: K. Syta, Archiwa magnackie w XVIII wieku: Studium kultury kancelaryjno-archiwalnej, Toruń 
[1] Acta komisyi hibernowych variorum annorum:

No 1 . Acta commissionis hybernorum annorum 1685, 1686 et 1687 sub regimine clavae ducatus JM Stanislai Jabłonowski, palatini Russiae, exercitus regni supremi ducis Leopoli expeditarum [B. Czart., sygn. 2701].

No 2. Actus komisyjej lwowskiej za powrotem z kampaniej JO JMP Kasztelana Krakowskiego, Hetmana Wielkiego Koronnego in anno Domini 1695 odprawionej hibernowej [B. Czart., sygn. 2425].

No 3. Actus komisyjej hibernowej lwowskiej po koronacyjej Najjaśniejszego Króla JM Augusta II po odprawionym kole generalnym wojska pod Rawą in anno 1698 [B. Czart., sygn. 2673, t. 1].

No 4. Actus komisyjej hibernowej w Lwowie odprawionej 1699 [B. Czart., sygn. 2673, t. 2].

No 5. Actus commissionis hibernalis Leopoliensis anno $1699[?]^{82}$.

No 5. Actus komisyjej hibernowej lwowskiej in anno 1700 [B. Czart., sygn. 2523].

$[\ldots]$

Te wszystkie akta introligowane in foliis.

[3] Acta hetmańskie dawne, wojskowe, ordynanse, likwidacyje wojsk Rzeczypospolitej etc., komputy:

No 12. Akta hetmańskie anni 1689 za buławy wielkiej JW JMP Stanisława Jabłonowskiego, wojewody ruskiego, hetmana wielkiego koronnego, w których ordynanse same do wojskowych polskiego i cudzoziemskiego autoramentu in variis bellicis wydawane, tudzież sądy hetmańskie wojskowe, dekreta, etc. [B. Czart., sygn. 2679].

No 13. Akta takież hetmańskie annorum 1692, 1693, 1694, w których similes actus ut supra w pierwszej księdze, ordynanse i różne dispositiones wojskowe [B. Czart., sygn. 2699].

No 14. Likwidacyja lwowska chorągwi i regimentów wojska koronnego, które się z Trybunału Skarbowego lwowskiego in anno 1691 we Lwowie odprawionego dostały na województwa [B.Czart., sygn. 2681].

No 15. Likwidacyja wojsk Rzeczypospolitej polskiego i cudzoziemskiego zaciągu na Trybunale Skarbowym Lwowskim anni 1697 odprawiona i przez województwa, gdzie płacą biorą konnotowana, ręką hetmańska podpisana [B. Czart., sygn. 2598].

[...]

[4] No 18. Komput wojska JeKróMci i Rzeczypospolitej koronnego na sejmie anni 1690 (supponitur warszawskim) ad no. 30 milia redukowany.

Podział wojska koronnego $\mathrm{z}$ komputu na sejmie tamże postanowionego in vim płacy na województwa z 45 podymnych i ten komput ręką hetmańską podpisany [B. Czart., sygn. 2562].

$[\ldots]$

Te także acta in foliis w księgi introligowane.

2010, passim) nie zawiera wszystkich akt z czasów hetmaństwa Jabłonowskiego w archiwum Sieniawskiego. Takie dokumenty znajdują się np. w jednostkach o sygnaturach 2640, czy 2563 (w zbiorach Biblioteki XX. Czartoryskich) - nie ujętych w sumariuszu. W nawiasach kwadratowych współczesne sygnatury opisanych przez Witoszyńskiego jednostek.

${ }^{82}$ Prawdopodobnie pomyłka: powtórny wpis jednostki o sygnaturze 2673, t. 2 (nr 4 w sumariuszu Witoszyńskiego). 
[7] Acta dyspozycyi i dystrybut hibern na wojsko Rzeczypospolitej koronne:

No 20. Płaca wojsku JKMści i Rzeczypospolitej polskiego i cudzoziemskiego zaciagu ad proportionem medietatis deklaracyi sejmu anni 1690 przez Trybunał Skarbowy Radomski anni 1692 za laski Oborskiego na województwa i ziemie ordynowana [B. Czart., sygn. 2680].

$[\ldots]$

[8] Konsystencyje wojska JKM i Rzeczypospolitej in visceribus regni po odprawionym kole generalnym pod Rawą die 4 Decembris 1697 anno rozdane [B. Czart., sygn. 2603].

$[\ldots]$

Te także wszystkie akta w księgach in foliis introligowane.

\title{
THE PEN IN THE SERVICE OF THE BULAVA. ANOTHER PORTRAYAL OF THE HETMAN CHANCELLERIES AND ARCHIVES OF STANISŁAW JABŁONOWSKI
}

\begin{abstract}
The paper depicts the chancellery and archive of the Grand Crown Hetman Stanisław Jabłonowski as an important tool of a hetman's power and control over the Polish-Lithuanian Commonwealth armed forces during the war with the Ottoman Empire between 1683 and 1699. The long-lasting military conflict brought about numerous challenges of logistical, financial and disciplinary nature. Thorough record-keeping could have been a source of significant help for the hetman in overcoming these difficulties.

The hetman's chancellery was responsible for issuing and keeping his documents. An exceptional role was played by military scribes - the heads of the hetman's chancellery. During the Jabłonowski hetmanship, Wojciech Stanisław Czacki and Szymon Franciszek Pułaski were successive military scribes. The scribes dealt with the detailed preparation of the contents of the documents issued by the hetman. Their function was also crucial in the distribution of special bonuses (Polish largicje) - a type of remuneration which was granted annually to high-ranking officers by the hetman from the Hiberna Treasury. The wars waged by the Polish-Lithuanian Commonwealth in the second half of the $17^{\text {th }}$ century and in the beginning of the 18th century were conducive to the development of military archives. Moreover, they contributed to the introduction of increasingly more bureaucratic forms of governing the army.
\end{abstract}

\section{STYLOS AU SERVICE DE BOULAVA. DERECHEF, DE LA CHANCELLERIE ET DES ARCHIVES DE L'HETMAN STANISLAW JABLONOWSKI}

\section{Resumé}

Cet article présente les caractéristiques de la chancellerie et des archives de l'hetman Stanisław Jabłonowski considérés comme l'outil important pour l'exercice du pouvoir et du contrôle des forces armées par l'hetman pendant la guerre de la République de Deux Nations avec l'Empire ottoman (1683-1699). Le conflit armé prolongé a entraîné de nom- 
breux problèmes logistiques, financiers et disciplinaires. Une documentation fiable aurait pu aider considérablement l'hetman à surmonter ces difficultés.

La chancellerie qui fonctionnait sous son patronat était responsable de la création et de la collecte des actes d'hetman. Les secrétaires militaires qui étaient les hauts fonctionnaires de la chancellerie d'hetman ont joué le rôle particulier. À l'époque de Stanisław Jabłonowski, la fonction du secrétaire militaire a été successivement exercée par Wojciech Stanisław Czacki et Szymon Franciszek Pułaski. Les secrétaires étaient tenus d'élaborer de manière détaillée des documents émis par l'Hetman. Ils ont joué un rôle considérable dans la répartition des "largicje » - rémunérations spéciales allouées chaque année par l'hetman à des officiers supérieurs de l'Armée polonaise et versées par le Trésor d'hiver. Les guerres menées par la République de Deux Nations dans la seconde moitié du XVII siècle et au début du XVIII ${ }^{\mathrm{e}}$ siècle ont favorisé le développement des archives militaires ainsi que la mise en place de formes plus bureaucratiques d'administration de l'armée. 